\title{
Deteksi Cemaran Mikroorganisme pada Kawasan Konservasi Penyu di Pangumbahan Sukabumi
}

\author{
Dewi Elfidasari ${ }^{1}$, Toufan Gifari ${ }^{2}$ dan Irawan Sugoro ${ }^{3}$ \\ ${ }^{1,2}$ Program Studi Biologi, Fakultas Sains dan Teknologi, Universitas Al Azhar Indonesia \\ ${ }^{3}$ Pusat Aplikasi Isotop dan Radiasi, Badan Tenaga Nuklir Nasional (PAIR-BATAN)
}

Penulis untuk Korespondensi/Email: $\underline{\text { d_elfidasari@uai.ac.id }}$

\begin{abstract}
Abstrak - Penyu hijau (Chelonia mydas) merupakan reptil ordo Testudines, famili Cheloniidae yang masuk dalam kategori terancam punah CITES Appendiks I. Populasi penyu hijau semakin menurun disebabkan berbagai macam faktor. Diduga mikroorganisme juga berperan dalam penurunan hasil penetasan. Oleh karena itu perlu dilakukan deteksi cemaran mikroorganisme di kawasan konservasi penyu pangumbahan. Sampel mikroorganisme diambil dari habitat peneluran hingga pra dan pasca penetesan. Kemudian mikroorganisme diidentifikasi menggunakan metode molekuler dan sequencing. Hasil identifikasi menunjukkan mikroorganisme pencemar murni Gram negatif yang bersifat patogen. Golongan bakteri koliform yang terdeteksi adalah E.coli, Salmonella dan Shigella, sedangkan jamur didominasi oleh kapang dan yeast.
\end{abstract}

Kata Kunci: penyu hijau, Chelonia mydas, cemaran mikroorganisme, konservasi penyu Pangumbahan.

Abstract - Green turtle (Chelonia mydas) is a reptile of Testudines, Cheloniidae family belonging to the endangered category of CITES Appendix I. The population of green turtles is declining due to various factors. Suspected microorganisms also play a role in decreasing hatchery results. Therefore it is necessary to detect microorganisms in the conservation area of turtle pangumbahan. Microorganism samples were taken from spawning habitat up to pre and post penetration. Then the microorganisms were identified using molecular method and sequencing. The identification results show that Gram negative pure microorganisms are pathogenic. Groups of coliform bacteria that are detected are E. coli, Salmonella and Shigella, while mushrooms are dominated by mold and yeast.

Keywords: Green Turtle, Chelonia mydas, microorganism pollution, Pangambahan Turtle Conservation.

\section{PENDAHULUAN}

$\mathrm{S}$ ejak 1970 populasi penyu hijau terus mengalami penurunan walaupun proteksi sudah diberlakukan (Spotila 2004). Perburuan illegal hingga upaya konservasi yang kurang maksimal belum mampu mengembalikan populasi penyu hijau seperti semula. Sejumlah penelitian membuktikan bahwa penurunan tingkat keberhasilan penetasan telur penyu disebabkan oleh interaksi bakteri dengan beberapa jenis telur penyu (Wyneken et al. 1988 ; Patino-Martinez et al. 2012).
Sebagai hewan yang memainkan peran penting dalam siklus detritus di laut, keberadaan penyu hijau perlu dijaga dan dilestarikan. Kawasan konservasi penyu pangumbahan merupakan area penangkaran yang fokus pada jenis penyu hijau. Kegiatan konservasi meliputi proses peneluran, penetasan telur dan pelepasan tukik. Penting sekali dilakukan analisis, identifikasi dan deteksi cemaran mikroorganisme di kawasan konservasi pangumbahan, sehingga upaya konservasi dapat berjalan maksimal. 


\section{Tujuan dan Manfaat}

Penelitian ini bertujuan untuk mendeteksi dan mengidentifikasi jenis-jenis mikroorganisme pencemar kawasan konservasi penyu Pangumbahan terutama di daerah pantai, habitat peneluran dan penangkaran penyu hijau (Chelonia mydas) yang diduga menjadi penyebab rendahnya jumlah telur penyu yang menetas.

Penelitian ini akan memberikan hasil berupa data keberadaan cemaran mikroorganisme pada kawasan konservasi penyu Pangumbahan yang dapat menjadi sumber referensi bagi pemerintah daerah dan pemerintan pusat dalam mengambil kebijakan terkait pengelolaan kawasan konservasi penyu Pangumbahan agar tidak terjadi penurunan populasi penyu akibat cemaran mikroorganisme di kawasan tersebut.

\section{METODE PENELITIAN}

\section{Waktu dan Lokasi Penelitian}

Penelitian ini dilakukan pada bulan Maret-Juli 2017. Pengambilan sampel dilakukan di UPTD Konservasi Penyu Pangumbahan, Sukabumi, Jawa Barat. Analisis keberadaan mikroorganisme pada tiap sampel dilakukan di Laboratorium Pusat Aplikasi Isotop dan Radiasi BATAN.

\section{Objek Penelitian}

Objek penelitian ini adalah sampel air laut, pasir di sarang alami, lendir kloaka induk pasca bertelur, pasir di sarang semi alami pra dan pasca penetasan, serta sampel telur segar dan telur yang gagal menetas dari kawasan konservasi penyu Pangumbahan.

\footnotetext{
Alat dan Bahan

Peralatan yang digunakan pada penelitian ini adalah cooling box, laminar air flow, autoklaf, vortex, thermalcycler (PCR), centrifuge, thermostat, magnetic stirrer, water bath, microcentrifuge tube, neraca anlitik, mikroskop, inkubator, sample tube, SV column, erlenmeyer, petri dish, beaker glass, pipette tips, micro pipette, L rod, ose, sendok, tabung dan botol steril, $\mathrm{pH}$ meter, multimeter, bunsen, kulkas, kamera DSLR, stopwatch, tali, tisu, kapas, sarung tangan, masker, kertas label, plastic wrap serta alumunium foil.
}

Bahan-bahan yang digunakan antara lain media Nutrient agar (NA), media Mac Conkey Agar (MCA), Media Salmonella Shigella Agar (SSA), Media Potato Dextrose Agar (PDA) dan Media E.Coli Agar (ECA), $\mathrm{NaCl}$ 0,85\%, akuades, bahan pewarnaan bakteri gram, absolute ethanol, buffer (BW, TW, AE, CL, BL), Proteinase K Solution, PCR mix (aquades, CyberGreen, forward primer, reverse primer, DNA solution), alkohol $70 \%$, serta aquabidest pro injection.

\section{Tahap Penelitian dan Cara Kerja}

Penelitian dibagi menjadi 2 tahapan, pertama tahap pengambilan sampel mikroorganisme dan kedua tahap analisis sampel mikroorganisme.

\section{Tahap Pengambilan Sampel}

Sampel dibagi menjadi 3 fase, fase 1 diambil dari proses peneluran yaitu sampel air laut yang diambil dari tiga lokasi pendaratan penyu dan diletakkan dalam sample tube. Selanjutnya sampel lendir kloaka dan telur segar diambil dari tiga induk penyu berbeda. Kemudian sampel pasir alami diambil dari tiga lokasi peneluran. Fase kedua meliputi sampel pasir semi alami di area penetasan (pra dan pasca penetasan). Fase terakhir adalah sampel telur busuk dan isi telur busuk pasca penetasan. Total sampel yang diperoleh adalah 8 jenis sampel dengan 3 pengulangan.

\section{Tahap Analisis Sampel}

\section{Persiapan Sampel}

Sampel yang diperoleh dari lokasi (pra dan pasca penetasan) dikemas dan dibawa menggunakan cooling box. Sampel cair (lendir kloaka dan air laut) diambil sebanyak $2 \mathrm{ml}$ kemudian ditepatkan menggunakan $\mathrm{NaCl}$ $0,85 \%$ hingga $10 \mathrm{ml}$. kemudian untuk sampel padat (pasir) diambil dan ditimbang sebanyak $0,5-1 \mathrm{~g}$ dan ditepatkan menggunakan $\mathrm{NaCl}$ 0,85\% hingga $5 \mathrm{ml}$. Persiapan yang dilakukan untuk sampel telur (telur segar dan gagal menetas) direndam dalam beaker glass berisi $\mathrm{NaCl}$ 0,85\% dan ditepatkan hingga $100 \mathrm{ml}$. Selanjutnya untuk sampel isi telur yang gagal menetas disiapkan dengan cara cangkang digunting dan dikeluarkan isi telur (albumin dan yolk), kemudian dipepet sebanyak $1 \mathrm{ml}$ dan ditepatkan menggunakan $\mathrm{NaCl}$ 0,85\% hingga $10 \mathrm{ml}$. Setelah itu semua sampel dipindahkan ke dalam tabung reaksi steril sebagai pengenceran 0 . 


\section{Enumerasi Mikroorganisme}

Seluruh sampel diambil sebanyak $100 \mu \mathrm{l}$ kemudian dibuat 8 kali pengenceran didalam microtube berisi $0,9 \mathrm{ml} \mathrm{NaCl} 0,85 \%$. Enumerasi mikroorganisme dari 19 jenis sampel dilakukan menggunakan metode spread plate. Enumerasi bakteri total dilakukan dengan mengambil $100 \mu$ l hasil pengenceran 0 hingga 8 dan dispread pada media NA. Jamur (kapang dan yeast) dienumerasi dengan mengambil 100 $\mu 1$ hasil pengenceran 0 hingga 8 dan dispread pada media SDA. Enumerasi E. coli dilakukan dengan spread hasil pengenceran 0 hingga 8 sebanyak $100 \mu \mathrm{l}$ menggunakan media ECA. Media SSA digunakan untuk enumerasi Salmonella Shigella dengan mengambil $100 \mu \mathrm{l}$ hasil pengenceran 0 dan dispread. Terakhir untuk koliform total dilakukan dengan mengambil $100 \mu 1$ hasil pengenceran 0 hingga 2 dan dispread menggunakan MCA.

\section{Perhitungan, Isolasi dan Pewarnaan Gram Bakteri}

Perhitungan bakteri total, koliform total dan $E$. coli, dilakukan menggunakan metode TPC (Total Plate Count) setelah diinkubasi selama 24 jam pada suhu ruang. Perhitungan Salmonella Shigella dan total jamur baru dilakukan setelah inkubasi selama 48 jam. Selanjutnya dilakukan pengamatan bentuk, warna dan ukuran tiap bakteri untuk kemudian diisolasi menggunakan metode gores. Hasil biakan murni yang didapat kemudian dibuat preparat dengan diratakan pada object glass dan dikeringkan. Setelah itu preparat diberikan 2-3 tetes larutan gram A dan dibiarkan 1 menit. Selanjutnya preparat dicuci dengan air mengalir dan dianginkan. Kemudian preparat diberikan 2-3 tetes larutan gram B dan dibiarkan selama 1 menit, lalu dicuci dengan air mengalir. Setelah dianginkan, preparat kembali diberi beberapa tetes larutan gram C hingga warna larutan sebelumnya luntur dan didiamkan beberapa menit. Terakhir preparat diberikan 2-3 tetes larutan gram $\mathrm{D}$ dan didiamkan selama dua menit, lalu dicuci dengan air mengalir. Selanjutnya preparat diamati menggunakan mikroskop dan difoto.

\section{HASIL DAN PEMBAHASAN}

Deteksi cemaran mikroorganisme di kawasan konservasi penyu Pangumbahan Hasil analisa deteksi cemaran mikroorganisme di kawasan konservasi penyu Pangumbahan menunjukkan bahwa keberadaan mikroorganisme terdeteksi di seluruh sampel (Tabel 1). Sampel lendir kloaka, telur segar, telur busuk, telur isi, pasir tempat peletakan telur, pasir tempat penetasan telur (pra dan pasca penetasan) serta sampel air laut positif mengandung mikroorganisme

Tabel 1. Hasil deteksi keberadaan mikroorganisme di kawasan konservasi penyu Pangumbahan.

\begin{tabular}{cc}
\hline Sampel & Mikroorganisme \\
\hline Lendir kloaka & positif \\
Telur segar & positif \\
Telur busuk & positif \\
Telur isi & positif \\
Pasir alami & positif \\
Pasir pra penetasan & positif \\
Pasir pasca penetasan & positif \\
Air laut & positif \\
\hline
\end{tabular}

Berdasarkan pengamatan makroskopik ditemukan 6 koloni bakteri yang berbeda dari seluruh sampel. Secara morfologi, bentuk koloni yang terdeteksi adalah bundar didominasi oleh koloni berwarna putih, kemudian hijau dan biru. Koloni berwarna putih memiliki dua ukuran yakni besar dan kecil. Setelah dilakukan pewarnaan Gram, diperoleh hasil bahwa koloni tersebut telah murni Gram negatif dan bersifat patogen. Hasil uji gram terhadap setiap isolat berdasarkan pewarnaan gram menunjukkan bahwa semua isolat murni berasal dari gram negatif dan bersifat patogen. Bentuk sel semua isolat bakteri adalah basil dengan ukuran yang berbeda (Gambar 1).

Hasil identifikasi jamur pada media PDA dari keseluruhan sampel menunjukkan jamur berasal dari golongan yeast dan kapang. Pengamatan koloni khamir dilakukan setelah sampel diinkubasi selama 24 jam, sedangkan kapang baru dapat diamati setelah 72 jam. Secara makroskopis, kapang yang terdeteksi memiliki bentuk bulat berhifa dan berlendir. 
Sedangkan yeast memiliki ukuran yang lebih kecil dan berlendir (Gambar 1).

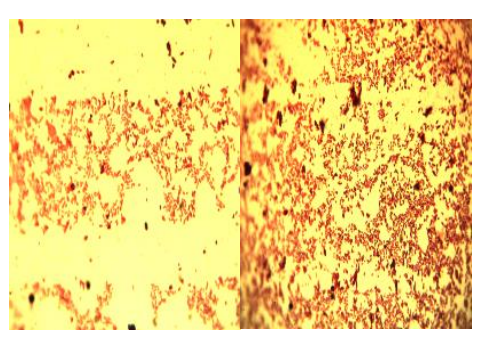

G. Isolat label 1

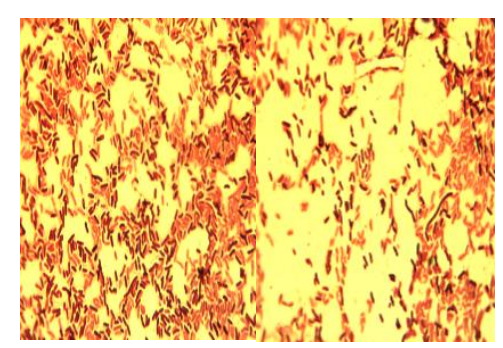

F. Isolat label 4

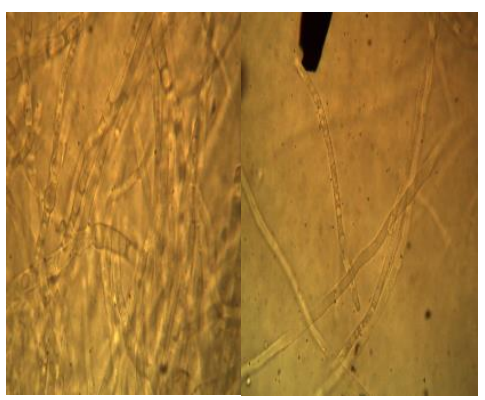

B. Kapang label T3

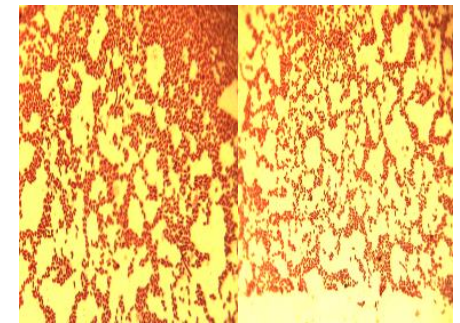

I. Isolat label 2

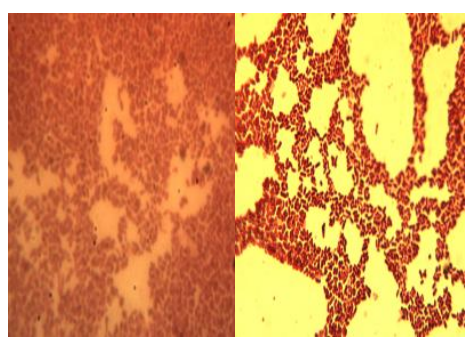

E. Isolat label 5

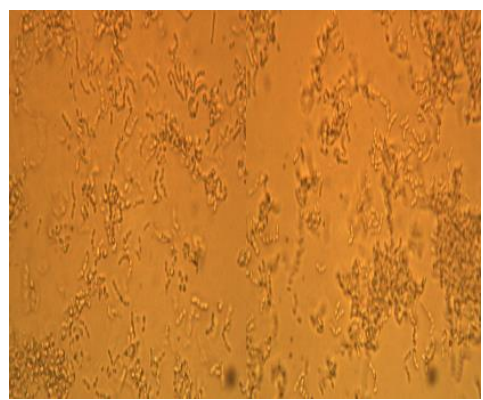

C. Yeast label 60

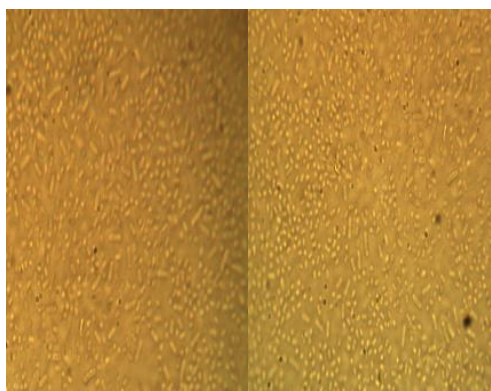

J. Yeast label T3a

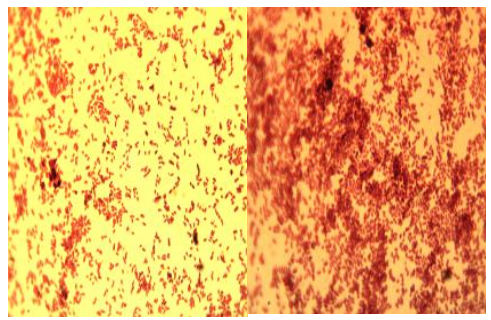

H. Isolat label 3

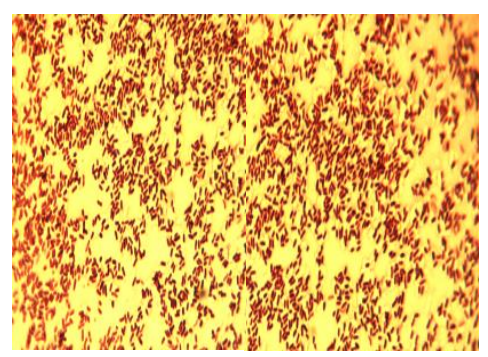

D. Isolat label 6

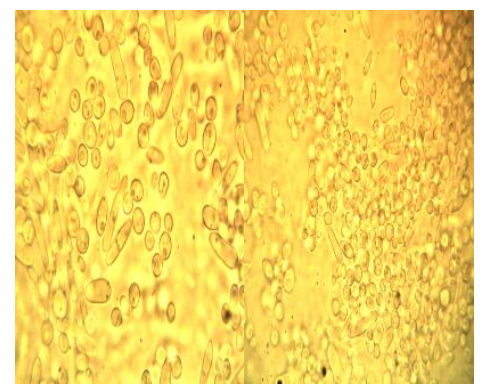

A. Yeast label T3

Gambar 1. Hasil uji keberadaan mikrooorganisme di kawasan konservasi penyu Pangumbahan. 
Jenis Mikroorganisme yang Dijumpai di Kawasan Konservasi Penyu Pangumbahan Mikroorganisme yang berhasil dijumpai di kawasan konservasi penyu Pangumbahan meliputi bakteri koliform, E.coli dan Salmonella Shigella. Berdasarkan hasil kuantifikasi log CFU mikroorganisme, ratarata enumerasi total mikorba, koliform, E. coli, dan jamur pada sampel fase (Lendir kloaka, air laut, telur segar dan pasir alami.) menunjukkan bahwa lendir kloaka memiliki tingkat cemaran tertinggi (Gambar 2). Lebih tingginya cemaran mikroorganisme pada lendir kloaka kemungkinan, disebabkan oleh kondisi pencernaan induk penyu. Alkindi et al. (2006) menyatakan bahwa kontaminasi mikroorganisme kemungkinan berasal dari sistem pencernaan induk penyu itu sendiri termasuk juga lubang kloaka. Karena pada dasarnya, lendir ini berupa cairan bening glikoprotein yang disekresikan dari kloaka, dan melapisi telur saat proses peneluran berlangsung (oviposisi). Oleh karena itu, perpindahan mikroorganisme ke telur mungkin saja dapat terjadi melalui lendir kloaka akibat sistem reproduksi induk penyu yang sudah terinfeksi bakteri dan jamur terlebih dahulu (Keene 2012). Sehingga dapat diduga bahwa saluran reproduksi induk penyu telah terinfeksi.

Berdasarkan hasil kuantifikasi enumerasi mikroorganisme fase 1 (Gambar 2), jumlah mikroorganisme pada cangkang telur segar lebih sedikit dibandingkan dengan lendir kloaka. Kemungkinan lendir kloaka telah menghambat pergerakan koliform, jamur, $E$. coli, Salmonella dan Shigella untuk menginvasi telur. Pada penyu sisik, lendir kloaka yang disekresikan mengandung sifat antimikroba untuk melindung telur dari mikroorganisme (Soslau et al. 2011; Phillott 2002). Percobaan yang dilakukan Ewert (1985) yaitu dengan mencuci lendir kloaka dari telur segar, dapat menyebabkan telur lebih mudah terinfeksi mikroba. Selanjutnya Phillott (2002) menemukan bahwa lendir kloaka juga dapat menghalangi pertumbuhan jamur selama beberapa hari. Jadi, jika lendir ini memiliki kemampuan untuk pertahanan terhadap jamur, mungkin terdapat kemampuan melawan pertumbuhan bakteri. Protein lain, seperti yang ditemukan di albumen telur, telah terbukti mampu memberikan pertahanan terhadap mikroorganisme (Phillott, 2002). Al-Bahry et al. (2009) menemukan bahwa konsentrasi bakteri terendah ada pada albumen telur, dan menghubungkan pengamatan ini dengan sifat pertahanan kimia antimikroba protein albumen. Ada kemungkinan protein serupa dapat hadir dalam cairan kloaka, sehingga memiliki pertahanan yang sama untuk melindungi telur. Sifat antimikroba mungkin ada di lendir kloaka, karena sifat antimikroba relatif umum terjadi pada kondisi alami seperti pada tumbuhan, invertebrata, dan vertebrata. Namun, tidak diketahui apakah lendir tersebut mampu menahan telur melawan mikroorganisme setelah mengering, terutama pada akhir inkubasi saat embrio paling rentan terinfeksi (Phillott, 2002). Hal ini mungkin dapat menjadi dugaan awal ketika hasil enumerasi mikroorganisme dari sampel fase $3^{1}$, yaitu sampel telur busuk pasca menetas memberikan hasil cemaran yang tinggi (Gambar 2). Terdeteksinya mikroorganisme pada isi telur pasca menetas dapat terjadi karena pori-pori pada lapisan cangkang menjadi lebih terbuka menjelang masa akhir inkubasi. Hal ini dapat menyebabkan mikroorganisme melakukan penetrasi dan berkoloni ke dalam komponen telur (Al-Bahry et al. 2004). Selain itu Berrang et al. (1996) menambahkan bahwa terdapat kemungkinan infeksi bakteri terhadap komponen telur sebelum cangkang terbentuk, karena indung telur dan uterus induk penyu yang sudah terlebih dahulu terinfeksi bakteri. Sedangkan pada pasir alami tidak terdeteksi keberadaan koloni E. coli maupun Salmonella dan Shigella. Keberadaan koloni Salmonella Shigella juga tidak terdeteksi pada sampel air laut, sehingga dapat dikatakan cemaran Salmonella Shigella berasal dari saluran pencernaan induk penyu yang terbawa oleh telur maupun lendir kloaka. Menurut Gantois et al. (2009), organ reproduksi induk penyu yang telah terinfeksi Salmonella dapat mengkontaminasi telur melalui filtrasi pada cangkang telur dan usus (kontaminasi feses) maupun kontaminasi langsung pada yolk, albumin dan cangkang sebelum oviposisi berlangsung.

\footnotetext{
${ }^{1}$ Telur busuk dan isi telur busuk.
} 


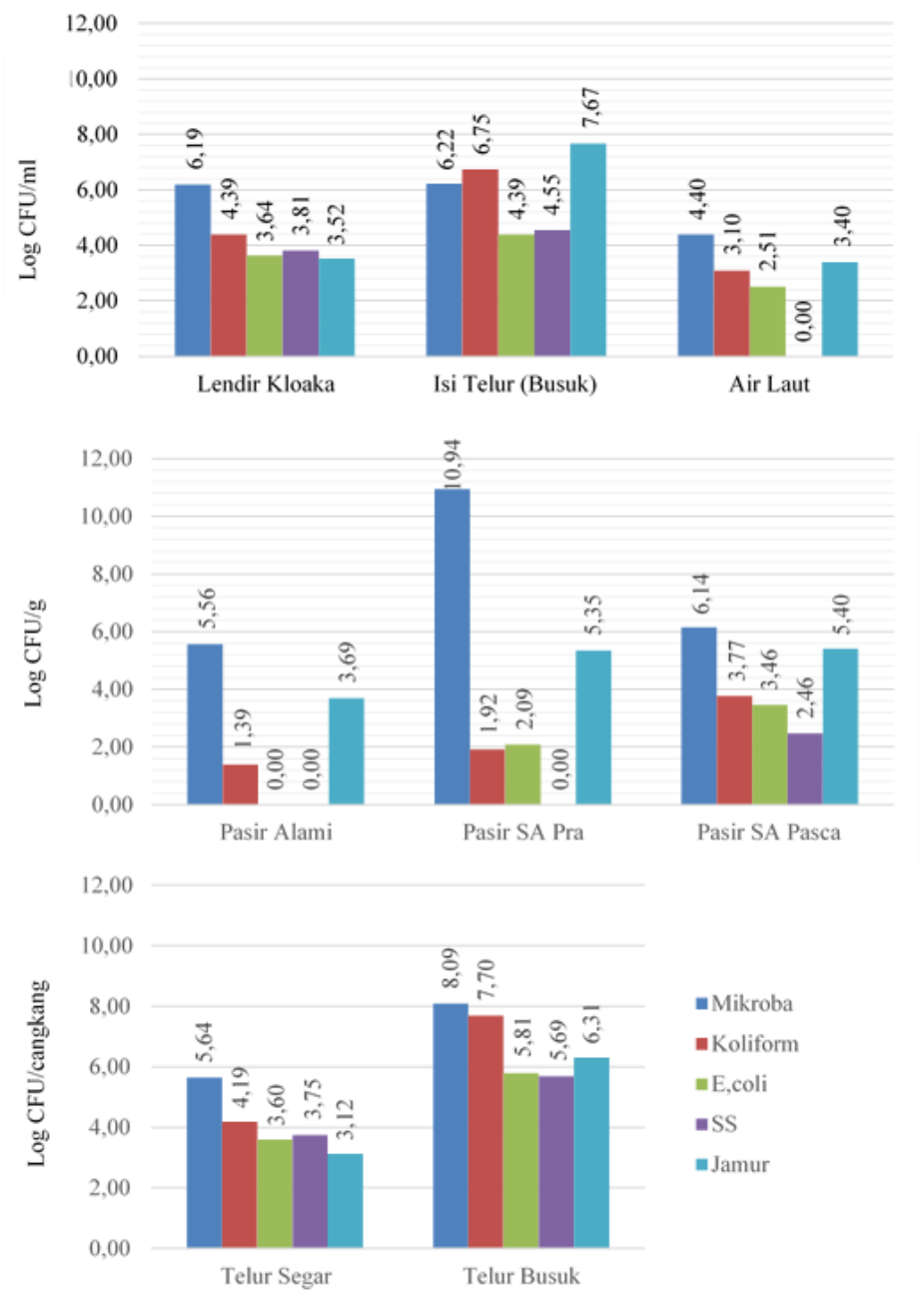

Gambar 2. Rata-rata enumerasi Log CFU mikroorganisme seluruh sampel

Hasil enumerasi sampel fase $2^{2}$ yaitu pasir semi alami pasca menetas meliputi total mikroba, koliform, E. coli, Salmonella Shigella dan jamur terdeteksi diseluruh sampel (Gambar 2). Jumlah mikroorganisme pada pasir sarang semi alami pasca menetas mengalami peningkatan kecuali pada pertumbuhan jamur. Menurut Simbolon (2008), hal ini terjadi karena adanya persaingan diantara mikroorganisme itu sendiri, diduga jamur kalah bersaing dalam memanfaatkan nutrisi untuk dapat tumbuh dan berkembang. Keberadaan koloni Salmonella Shigella serta peningkatan jumlah koloni mikroba pada pasir semi alami pasca menetas disebabkan oleh proses penggalian dan penutupan sarang yang menyebabkan mikroorganisme terdispersi ke seluruh bagian

\footnotetext{
2 Pasir Semi Alami pra dan pasca
}

sarang. Selain itu mikroba juga dapat berasal dari induk penyu yang terbawa oleh telur. Keadaan ini bertambah buruk jika dalam satu sarang ada beberapa telur yang infertil atau fertil tetapi tidak mampu berkembang sempurna sehingga dapat memicu kolonisasi mikroorganisme dan mengancam perkembangan seluruh telur (Robinson et al. 2003). Selanjutnya, mikroorganisme memanfaatkan kalsium $\left(\mathrm{CaCO}_{3}\right)$ pada cangkang telur untuk tumbuh dan berkembang dengan cara memperkuat dinding sel serta membentuk ikatan protein - kalmodulin dan terbentuklah $\mathrm{Ca}$ - kalmodulin yang berfungsi dalam aktivasi enzim-enzim sitosol (Salisbury \& Ross 1993).

Keberadaan koloni mikroorganisme pada sampel telur gagal menetas (busuk) baik isi maupun cangkang telur (Gambar 2) 
menunjukkan bahwa mikroorganisme telah berhasil melakukan penetrasi ke dalam telur melalui pori-pori cangkang. Limpus et al. (2008) menyatakan bahwa pori-pori pada permukaan cangkang telur berfungsi untuk pertukaran gas, uap air dan panas dari lingkungan eksternal. Akan tetapi, Al-Bahry et al. (2011) menambahkan bahwa selain penting dalam menunjang perkembangan embrio, poripori juga berpotensi menjadi jalur filtrasi mikroorganisme. Menurut Bilinski et al. (2001) seharusnya 43\% kalsium pada cangkang telur digunakan untuk proses perkembangan embrio (osteogenesis). Akan tetapi, aktivitas jamur yang mengkonsumsi kalsium pada lapisan cangkang dapat menyebabkan proses pengikisan (Phillot et al. 2006). Selanjutnya, pengurangan kalsium pada cangkang akan sejalan dengan pertumbuhan hifa hingga menutup pori-pori cangkang yang berdampak pada penyumbatan pertukaran gas. Kemudian penetrasi hifa dilanjutkan hingga ke embrio yang menyebabkan kematian embrio (Phillot et al. 2006). Pada dasarnya, awal penetrasi mikroorganisme hingga dapat berkoloni pada komponen telur (yolk dan albumin) terjadi ketika struktur lapisan cangkang telah rusak (Al-Bahry et al. 2004).

\section{KESIMPULAN DAN SARAN}

\section{Kesimpulan}

Cemaran mikroorganisme terdeteksi hampir di seluruh sampel, Hasil identifikasi dan uji Gram menunjukkan jenis mikroorganisme yang terdeteksi adalah bakteri gram negatif (koliform), E.coli, Salmonella dan Shigella, sedangkan jamur didominasi kapang dan yeast.

\section{Saran}

Identifikasi mikroorganisme masih menunggu hasil uji molekuler (Sequencing) sehingga identifikasi bisa lebih dipertajam hingga ke spesies.

\section{DAFTAR PUSTAKA}

[1] Al-Bahry SN, Mahmoud IY, Al-Harthy A, Elshafie AE, Al-Ghafri S, Alkindi AYA \& Al-Amri I. 2004. Bacterial contamination in freshly laid egg green turtles Chelonia mydas at Ras Al Hadd reserve, Oman. In: 24 th International
Symposium for Sea Turtles. San Jose, Costa Rica.

[2] Al-Bahry SN, Mahmoud IY, Elshafie AE, Al-Hasby A, Al-Ghafei S, Al-Amri I \& Al-Kindi AYA. 2009. Ultrastructure features and elemental distribution in eggshell during pre and post hatching periods in the green turtles Chelonia mydasat Ras Al-Hadd Oman. Tiss cell, vol. 42, no. 1, pp. 214-221.

[3] Alkindi AYA, Mahmoud IY, Woller MJ, Plude JL. 2006. Oviductal morphology in relation to hormonal levels in the snapping turtle, Chelydra serpentine. Tiss Cell 38:19-33.

[4] Berrang M, Frank JF, Buhr RJ, Bailey JS, Cox NA. 1996. Effect of hatching cabinet sanitation treatments on Salmonella cross-contamination andhatchability of broiler eggs. Poul Scie 75:191-196.

[5] Bilinski JJ, Reina RD, Spotila JR, Paladino FV. 2001. The effects of nest environment on calcium mobilization by leatherback turtle embryos (Dermochelys coriacea) during development. Com Biochem Phys Part A: Phys 130:151-162.

[6] Ewert M. 1985. Embryology of turtles. Dalam : Gans C, Billeu F, Maderson P. Ed.

[7] Biology of the Reptilia. Vol. 14A. New York: John Wiley and Sons.

[8] Gantois I, Ducatelle R, Pasmans F, Haesebrouck F, Gast R, Humphrey TJ, Immerseel FV. 2009. Mechanisms of egg contamination by Salmonella Enteritidis. FEMS Microbiol Rev 33:4.

[9] IUCN. 2015. Chelonia mydas. http://www.iucnredlist.org/details/summ ary/4615/0 (Diakses pada 15 April 2016).

[10] Keene. 2012. Microorganisms from Sand, Cloacal Fluid, and Eggs of Lepidochelys olivaceaand Standard Testing of Cloacal Fluid Antimicrobial Propertie. [tesis]. University of Indiana.

[11] Limpus CJ, Kennett R, Whiting S. 2008. A Biological Review of Australian Marine Turtle Species. 2. Green Turtle, Chelonia mydas (Linnaeus). Queensland: Environmental Protection Agency.

[12] Patino-Martinez J, Marco A, Quinones L, Abella E, Abad R \& Dieguez- 
Uribeondo J. 2012. Hoe do hatcheries influence embryonic development of sea turtle eggs? Experimental analysis and isolation of microorganisms in leatherback turtle eggs. J. of Exp. Zool. Vol. 317, no. 1, pp. 47-54.

[13] Phillot AD. 2002. Fungal colonization of sea turtle nests in Eastern Australia. [disertasi]. Central Queensland University.

[14] Phillot AD, Parmenter CJ, McKillup SC. 2006. Calcium depletion of eggshell after fungal invasion of sea turtle eggs. Chelon Conserv Biol 5:146-149.

[15] Robinson J, Griffiths RA. Jeffries P. 2003. Suscept ibility of frog (Rana temporaria) and toad (Bufo bufo) eggs to invasion by Saprolegnia. Amphi Reptil 24:261-268.

[16] Salisbury FB, Ross CW. 1995. Fisiologi Tumbuhan. Bandung: ITB. 132-135.

[17] Simbolon Dennita. 2008. Penambahan mikroorganisme dan asam humik pada tanah latosol dan tanah tailing untuk meningkatkan pertumbuhan dan produksi tanaman jagung (Zea mays L..). [Skripsi]. Bogor : Institut Pertanian Bogor.
[18] Soslau G, Russell JA, Spotila JR, Mathew AJ\& Bagsiyao P. 2011.

[19] Acinetobacter sp. HM 746599 isolated from leatherback turtle blood. FEMS

[20] Microbiology Letters. 322: 166-171.

[21] Spotila JR. 2004. Sea Turtles. A Complete Guide to Their Biology, Behavior, and Conservation. Baltimore : John Hopkins University.

[22] Wicaksono MA. 2014. Analisis mikroorganisme pada telur penyu hijau (Chelonia mydas) dari Taman pesisir pantai penyu pangumbahan Sukabumi. [Skripsi]. Jakarta : Universitas Al-Azhar Indonesia.

[23] Wyneken J, Burke $\mathrm{T}$ \& Pedersen D. 1988. Egg failure in natural and relocated sea turtle nest. J. of Herpetology. Vol. 22, no. 1, pp. 88-96. 